DOI 10.37882/2223-2982.2020.11.38

\title{
ТРАНСФОРМАЦИЯ ИСТОРИЧЕСКОЙ ПАМЯТИ О ПЕРВОЙ МИРОВОЙ ВОЙНЕ НА СТРАНИЦАХ «ИСТОРИЧЕСКОГО ЖУРНАЛА» (1937 - 1945 ГГ.)
}

\section{THE TRANSFORMATION OF HISTORICAL MEMORY OF THE FIRST WORLD WAR ON THE PAGES OF "HISTORICAL MAGAZINE" (1937 - 1945)}

\section{A. Shlyakhov}

Summary: This article presents the results of one of the paragraphs of the dissertation research, which is devoted to the analysis of the transformation of the historical memory of the First World War on the pages of the «Historical Journal» (1937 - 1945). Object of research: World War I in Russia; subject of research: publications about the First World War on the pages of the «Historical Journal» (1937 - 1945); goal: consideration of the transformation of views on the First World War on the pages of the «Historical Journal» in the specified period. The assumption is made that on the pages of «Historical Journal» (1937 - 1945) the First World War «was not forgotten»; there was a gradual terminological, substantive and political transformation of the historical memory of the First World War. From a terminological point of view, there was a gradual shift in emphasis from the «imperialist» character of the war to the «world» character of the war. From a substantive point of view, there was no significant change in the interpretation of the causes of the origin of the First World War, however, there was a certain change in the interpretation of the perpetrators of the outbreak of the First World War. The political transformation of the First World War was characterized by drawing historical parallels with past, current and future events. At the same time, the parallel between the First World War and current events, as a rule, had a pronounced applied orientation - the formation of public opinion regarding the current political situation through the prism of past events; the parallels between the First World War and forecasted future events were built on the formation of the desired image of the future. Much attention was paid to the methodological side of the formation of the historical memory of the First World War.

Keywords: historical memory, transformation of the historical memory, "Historical magazine".

\author{
Шляхов Алексей Владимирович \\ Аспирант, ФГАОУ ВО «Самарский начиональный \\ исследовательский университет \\ имени академика С.П. Королева». \\ shlalvl@yandex.by
}

Аннотация: В настоящей статье представлены результаты одного из параграфов диссертационного исследования, который посвящен анализу трансформации исторической памяти о Первой мировой войне на страницах «Исторического журнала» (1937 - 1945 гг.). Объект исследования: Первая мировая война в России; предмет исследования: публикации о Первой мировой войне на страницах «Исторического журнала» (1937 - 1945 гг.); цель: рассмотрение трансформации взглядов на Первую мировую войну на страницах «Исторического журнала» в указанный период. Делается предположение 0 том, что на страницах «Исторического журнала» (1937 - 1945 гг.) Первая мировая война «не забывалась»; происходила постепенная терминологическая, содержательная и политическая трансформация исторической памяти о Первой мировой войне. С терминологической точки зрения, происходило постепенное смещение акцента с «империалистического» характера войны на «мировой» характер войны. С содержательной точки зрения, не наблюдалось существенного изменения в трактовке причин происхождения Первой мировой войны, однако наблюдалось определенное изменение в трактовке виновников развязывания Первой мировой войны. Политическая трансформация Первой мировой войны характеризовалась проведением исторических параллелей с прошедшими, текущими и будущими событиями. При этом параллель между Первой мировой войной и текущими событий, как правило, имела ярко выраженную прикладную направленность - формирование общественного мнения относительно актуальной политической обстановки через призму событий прошлого; параллели между Первой мировой войной и прогнозируемыми будущими событиями строились на формировании желаемого образа будущего. Большое внимание уделялось методологической стороне формирования исторической памяти о Первой мировой войне.

Ключевые слова: историческая память, трансформация исторической памяти, журнал «Исторический журнал».
$\Pi$ ервая мировая война - один из самых широкомасштабных вооруженных конфликтов в мировой истории, который составляет важную веху в современной мировой истории, равно как и в национальных историях испытавших на себе ее воздействие стран $[1$, c.645]

Актуальность изучения вопросов трансформации исторической памяти о Первой мировой войне в России обуславливается теоретической значимостью (потребность в написании с методологических позиций исторической памяти комплексных научных работ, объединяющих значительный массив данных по Первой мировой войне), социальной важностью (потребность в обеспечении использования исторического и культурного наследия для воспитания и образования подрастающего поколения) и практической значимостью данной темы (возможность обобщения и использования полученных 
результатов в аналитической деятельности общественных организаций и государственных органов).

При этом к числу источников исторической памяти традиционно относятся исторические журналы.

С учетом этого, а также принимая во внимание то, что историческая память как символическая репрезентация исторического прошлого трактуется в научной литературе в качестве составляющей самоидентификации индивида, социальной группы и общества [2, с.10], представляется, что анализ трансформации исторической памяти о Первой мировой войне, в т.ч. на страницах отечественных исторических журналов, обладает высокой степенью актуальности.

В настоящей статье представлены результаты одного из параграфов диссертационного исследования, который посвящен анализу трансформации исторической памяти о Первой мировой войне на страницах «Исторического журнала» (1937 - 1945 гг.).

Объектом исследования является Первая мировая война в России; предметом исследования - публикации о Первой мировой войне на страницах 86 номеров «Исторического журнала» (1937 - 1945 гг.) (совмещенные номера журнала считались за один номер); целью - рассмотрение трансформации взглядов на Первую мировую войну на страницах «Исторического журнала» в указанный период.

Гипотезой исследования является предположение о том, что на страницах «Исторического журнала» Первая мировая война «не забывалась»; происходила постепенная терминологическая, содержательная и политическая трансформация исторической памяти о Первой мировой войне.

На основе «сплошного» анализа номеров «Исторического журнала» из многочисленных публикаций в журнале выбирались те, где затрагивалась проблематика истории Первой мировой войны.

В частности, в предмет анализа включались как специализированные статьи, посвященные различным аспектам Первой мировой войны, так и статьи, в которых события Первой мировой войны выступали в качестве значимого фона для темы статьи (например, яркий пример, иллюстрация, сравнение, описание обстановки и т.п.). В то же время в предмет анализа не включались статьи, в которых события Первой мировой войны упоминались, однако не представляли существенного значения (например, упоминание Первой мировой войны никоим образом не увязывалось с ключевой идеей статьи либо присутствовало в качестве «побочного нарратива», как обозначение хронологических границ и т.п.).
В основу анализа положен хронологический принцип (январь - декабрь каждого анализируемого года).

Характеризуя направленность публикаций «Исторического журнала» (1937 - 1945 гг.), следует отметить, что журнал, будучи продолжением журнала «Борьба классов», являлся научно-популярным массовым изданием по всему кругу исторических вопросов (в 1941 году журнал был слит с журналом «Историк-марксист» и с декабря 1941 года стал органом Института истории Академии наук СССР; до 1941 года ответственным редактором журнала был Б.М. Волин, затем Ем. Ярославский). В журнале, помимо прочего, публиковались рецензии, библиографические заметки и материалы дискуссий по широкому кругу исторических проблем.

Таким образом, необходимо констатировать, что «Исторический журнал» является важным историческим источником для изучения трансформации взглядов на Первую мировую войну в период с 1937 по 1945 годы.

Анализ статей «Исторического журнала», подпадающих под предмет нашего исследования в 1937 году [3, с.427], в 1938 году [4, С. 85-94], в 1939 году [5, С. 53-54], в 1940 году [6, С. 37-57], в 1941 году [7, С. 35-45], в 1942 году [8, С. 3-15], в 1943 году [9, с. 43], в 1944 [10, С. 64-72] году и в 1945 году [11, С. 22-33], свидетельствует о следующем.

С 1937 года по 1945 год в «Историческом журнале» происходила постепенная терминологическая, содержательная и политическая трансформация исторической памяти о Первой мировой войне.

С терминологической точки зрения, происходило постепенное смещение акцента с «империалистического» характера войны («империалистическая война», «империалистская война») на «мировой» характер войны («мировая война», «первая мировая война»).

С содержательной точки зрения, не наблюдалось существенного изменения в трактовке причин происхождения Первой мировой войны; данные причины фактически сводились к двум вариантам - сложившейся системе империалистических противоречий и стремлению к переделу мира (остальные события были лишь формальным отражением глубинных причин - например, сараевское убийство и нападение на Сербию).

При этом с началом Второй мировой войны предлагалась следующая «мемориальная» логическая конструкция: окончание Первой мировой войны - подготовка новой мировой войны - продолжение вооруженных конфликтов и малых войн в разных частях света - агрессивная политика блока «Рим - Берлин - Токио».

В то же время наблюдалось определенное измене- 
ние в трактовке виновников развязывания Первой мировой войны.

В частности, в 1940 году (и отчасти в 1939 году) «маятник вины» в Первой мировой войне качнулся в сторону Англии и Франции (что соответствовало попыткам СССР отодвинуть надвигающуюся войну с нацистской Германией); в другие годы (и в особенности с началом Великой отечественной войны) ведущая роль в развязывании войны приписывалась Германии (германскому империализму, магнатам германской индустрии).

При объяснении мотивов России при вступлении в Первую мировую войну акцент делался на вынужденном характере вступления в войну вследствие совокупности внешних и внутренних политических обстоятельств; мотив захвата Россией проливов также рассматривался через призму ее соперничества с Германией.

Фокус ассоциирования Первой мировой войны с теми или иными историческими периодами, именами, событиями, процессами и проч. содержательно меняется.

Так, если память о войне не выходит за рамки периода первой половины 19 века - первой половины 20 века, то внутреннее наполнение данного периода постепенно становится богаче (например, существенным образом расширяется круг политических, военных, дипломатических и экономических деятелей, с чьими именами связывается память о Первой мировой войне: в «мемориальную орбиту» включаются не только крупные исторические фигуры, но и менее известные широкой публике личности).

Отсылка к тем или иным историческим фигурам характеризуется конкретизацией их деятельности. При этом имеют место процессы сравнения персоналий в исторической перспективе.

Все годы выхода «Исторического журнала» характеризуются содержательной связью памяти о Первой мировой войне с конкретными военными сражениями и операциями на различных театрах военных действий. При этом делается акцент на зверствах немецких военных, поражениях немецкой армии и успешных действиях русской армии (помощи со стороны русской армии).

Из множества межгосударственных договоров и союзов второй половины

19 - первой четверти 20 века на первый план постепенно выходят Брестский мир и Версальский мирный договор (Брестский мир традиционно трактуется как «грабительский мир», который в конкретных исторических условиях стал единственным способом выживания для советской власти и способствовал ее «упрочению»; Версальский мирный договор - как договор, который предопределил последующие реваншистские настроения Германии и породил англо-французские противоречия).

Первая мировая война содержательно связывается с множеством политических явлений, событий и процессов, однако фокус ассоциирования Первой мировой войны с различными событиями приобретает выраженную международную направленность, и по мере приближения к окончанию Великой отечественной войны наблюдается расширение спектра политических явлений, событий и процессов, связываемых с Первой мировой войной.

С содержательной точки зрения, негативным явлениям российской действительности военного и предвоенного периодов противопоставляются героические действия русской армии.

При этом на постоянной основе подчеркивается, что в годы Первой мировой войны Россия неоднократно спасала союзников от ударов германских вооруженных сил ценой собственных потерь, а роль русского народа в разгроме Германии в Первой мировой войне была решающей. Одновременно говорится о негативных сторонах немецкой политики предвоенного и военного времени.

Публикации «Исторического журнала» характеризуются привлечением такого «мемориального материала» о Первой мировой войне, который в полной мере (в зависимости от конкретного года) соотносится с существовавшей международной обстановкой.

При этом при оценке тех или иных событий, процессов и исторических личностей, связанных с Первой мировой войной, имеет место как определенная «генеральная мемориальная линия» (например, негативная оценка германского империализма и немецких территориальных интересов; положительная оценка боевых качеств русских солдат), так и вкрапление важных на определенный момент оценок (например, 1939 год: нейтральная оценка наличия накануне Первой мировой войны тройственного союза и франко-русского союза как враждебных военно-политических группировок; негативная оценка деятельности Троцкого и Бухарина; положительная оценка борьбы Ленина и Сталина «против провокаторов войны»; положительная оценка деятельности ВКП (б) как единственной партии, которая предвидела неизбежность Первой мировой войны задолго до ее начала; 1940 год: положительная оценка деятельности Сталина и независимое формулирование им выводов, аналогичных ленинским, а также негативная оценка «шпионско-провокаторской деятельности» английской контрразведки; 1941 год: критическая оценка терри- 
ториальные завоеваний и военных успехов Германии в Первой мировой войне в связи с тем, что они не могли обеспечить Германии стратегическую победу в силу затяжного характера боевых действий, значительного объема ресурсов антигерманской коалиции, а также нестабильности немецкого «политического тыла»; 1942 год: нейтральная оценка перенапряжения сил русских армий в годы Первой мировой войны; 1943 год: положительная оценка желания буковинского народа воссоединения с украинским народом после окончания Первой мировой войны).

Кроме того, в 1940 году акцентируется внимание на негативных сторонах англо-французской политики (например, на попытках англо-французской дипломатии спровоцировать конфликт между Россией и Германией и планах Англии и Франции «загребать жар чужими руками»).

Имеются признаки того, что выбор для оценки тех или иных событий и процессов, связанных с Первой мировой войной, носит целенаправленный характер (например, 1939 год - год начала Второй мировой войны и агрессивной политики фашистской Германии: негативная оценка позиции о «голубиной невиновности» Германии и ее «вынужденной обороне» против враждебного окружения в 1914 году; 1940 год - год попытки оттянуть надвигающуюся войну с фашистской Германией: негативная оценка англо-французской политики нейтралитета и Польши как «самого уродливого детища» Версальского мирного договора; 1941 год - год начала Великой отечественной войны и роста потребности СССР в ресурсах: нейтральная оценка превращения за годы Первой мировой войны США в одну из самых могущественных империалистических держав мира; 1942 год - год заключения англо-советско-иранского договора по поддержке военно-экономической деятельности гражданским путем и год возможного вступления Турции во Вторую мировую войну на стороне Германии в случае падения Сталинграда: негативная оценка связи германского милитаризма с «идеологией пруссачества» и «бессмертностью» Бисмарка в Германии - «Бисмарк in infinitum»; негативная оценка втягивания германским империализмом в Первую мировую войну Ирана; негативная оценка вступления в Первую мировую войну на стороне Германии Оттоманской империи; 1943 год - год проведения Тегеранской конференции: негативная оценка попытки германской дипломатии накануне Первой мировой войны использовать англо-российские противоречия на Ближнем Востоке в своих интересах; 1944 год - год проведения Нормандской операции: положительная оценка вступления Англии и США в Первую мировую войну; негативная оценка попыток Германии расколоть единство Антанты; 1945 год - год окончания Великой отечественной войны: негативная оценка деятельности Пангерманского союза, стремившегося развязать Первую мировую войну до заключения союза России, Франции и Англии).

При этом в орбиту оценки включается максимально большое количество событий, процессов и явлений, связанных с Первой мировой войной, а при оценках российских военных и политических деятелей имеет место контрастирование.

С точки зрения политической трансформации Первой мировой войны, на протяжении всего периода выхода «Исторического журнала» наблюдается в целом схожая трактовка Первой мировой войны; говорится о том, что Первая мировая война не была «народной войной».

При этом сама политическая трансформация Первой мировой войны характеризуется проведением исторических параллелей с прошедшими, текущими и будущими событиями.

Так, с точки зрения событий прошлого, имеет место сравнение Первой мировой войны с франко-прусской войной 1870 - 1871 годов, русско-японской войной 1904 - 1905 годов (волокита при принятии решений), а также в целом между немецкой военной стратегией в период второй половины 19 века и в период Первой мировой войны. При этом проводится параллель между пангерманизмом и национал-социализмом (подведение «национального» фундамента под империалистическую войну, восхваление захватнической политики, антисемитизм, расовая политика).

Параллель между Первой мировой войной и текущими событий, как правило, имеет ярко выраженную прикладную направленность - формирование общественного мнения относительно актуальной политической обстановки через призму событий прошлого. При этом особым образом акцентируется внимание на вопросах военной стратегии.

В то же время при проведении параллелей между Первой мировой войной и текущими событиями имеет место выявление не только сходств, но и различий.

Параллели между Первой мировой войной и прогнозируемыми будущими событиями строятся на формировании желаемого образа будущего посредством построения логической цепочки: «Германия делала тото в Первую мировую войну» - «Германия делает то-то сейчас» - «Германия по-прежнему Германия» - «Германия потерпела поражение в Первую мировую войну» «Германия потерпит поражение вновь».

Большое внимание уделяется методологической стороне формирования исторической памяти о Первой мировой войне. 
В частности, подвергаются резкой критике исследования о Первой мировой войне историка М.Н. Покровского и представителей его «школы», а также соответствующий пласт статей в журналах «Красный архив» и «Историк-марксист» (хотя в 1942 году имеет место привлечение даже этого материала).

В «круг чтения» попадает не только отечественный художественный материал, но и широкий спектр иностранной мемуарной и публицистической литературы.

Более того, в число источников формирования исторической памяти о Первой мировой войне вовлекаются работы авторов, чьи имена на страницах исторических журналов ранее можно было встретить, по меньшей мере, крайне редко.

Соответственно, фактически нивелируется тезис о том, что историческая память об исторических событи- ях должна ориентироваться на труды большевистских историков (характерная позиция, скажем, для журнала «Историк-марксист»).

Говорится об издании одного из томов «Всемирной истории», посвященного Первой мировой войне (ранее подготовка отдельного издания не относилась к числу приоритетов), а также о необходимости при формировании исторической памяти у школьников объяснять им значение каждого социально-исторического явления, в т.ч. посредством привлечения художественного и краеведческого материала, а также «эго-источников».

Таким образом, можно сделать вывод о том, что вопросам формирования и использования исторической памяти о Первой мировой войне на страницах «Исторического журнала» уделялось большое внимание, в том числе для решения актуальных политико-идеологических целей государства.

\section{ЛИТЕРАТУРА}

1. Мировые войны XX века: В 4 кн. Кн. 1: Первая мировая война: Ист. очерк / Отв. ред. Г.Д. Шкундин, 2002. 686 с. С. 645.

2. Репина Л.П. Культурная память и проблемы историописания (историографические заметки). М.: ГУ ВШЭ, 2003. 44 с. С. 10.

3. Ефимов Г. Сун Ят-Сен в борьбе за независимый Китай. // Исторический журнал. 1937. № 1. С. 96-112

4. Ронин С. Победа Ленинской политики завоевания передышки (к истории брестлитовского мирного договора). // Исторический журнал. 1938 . № 2. C. 24-37

5. Саморуков Н. Большевики на международной арене до мировой войны. // Исторический журнал. 1939. № 1. С. 47-59. С. 53-54

6. Питерский А. Жизнь Иосифа Виссарионовича Сталина в материалах Музея Революции ССсР. // Исторический журнал. 1940. № 1. С. 37-57

7. Черменский Е. Кадеты накануне февральской буржуазно-демократической революции 1917 года. // Исторический журнал. 1941. № 3. С. 35-45

8. Панкратова А. Двадцатипятилетняя годовщина свержения самодержавия. // Исторический журнал. 1942. № 3-4. С. 3-15

9. Штейнберг Е. Германский империализм на Ближнем Востоке накануне мировой войны 1914 - 1918 годов. // Исторический журнал. 1943. № 1. С. 54-67; Никитинский И. Немецкий шпионаж в России во время войны 1914 - 1918 гг. М. Госполишздат. 1942, 48 стр. // Исторический журнал. 1943. № 1.

10. Нотович Ф. Военный разгром и капитуляция Германии в 1918 году. // Исторический журнал. 1944. № 1. С. 64-72

11. Гуральский А. Из истории пангерманизма. // Исторический журнал. 1945. № 5. С. $22-33$.

( ) Шляхов Алексей Владимирович (shlalvl@yandex.by). 